\title{
Plants used in the treatment of piles by the scheduled caste community of Andro village in Imphal East District, Manipur (India)
}

\author{
Thiyam Tomba Singh ${ }^{1}$, Hanjabam Manoranjan Sharma ${ }^{1}$, Anoubam Radhapyari Devi ${ }^{2}$, \\ Hanjabam Rajanikanta Sharma ${ }^{3}$
}

${ }^{1}$ Department of Botany, Thoubal College, Thoubal (Manipur)-795138, India
${ }^{2}$ P.G. Department of Botany, D.M. College of Science, Imphal (Manipur)-795001 India
${ }^{3}$ Indian Institute of Science Education and Research (IISER), Mohali (Punjab)- 160055 India

Email address:

manoranjan_hanjabam@yahoo.com (H. M. Sharma), rajhanjabam@yahoo.com (H. R. Sharma)

\section{To cite this article:}

Thiyam Tomba Singh, Hanjabam Manoranjan Sharma, Anoubam Radhapyari Devi, Hanjabam Rajanikanta Sharma. Plants Used in the Treatment of Piles by the Scheduled Caste Community of Andro Village in Imphal East District, Manipur (India). Journal of Plant Sciences. Vol. 2, No. 3, 2014, pp. 113-119. doi: 10.11648/j.jps.20140203.13

\begin{abstract}
The present study was carried out at Andro Village in Imphal East district (Manipur) in the remote North-Eastern corner of India. The village is inhabited by a scheduled caste community known as 'Lois'. The scheduled caste people of Andro Village have a very good knowledge about the treatment of various diseases and ailments with plants. Hemorrhoids' (Piles) is commonly occurring ailment in Andro village and the villagers treat Piles successfully with the help of different plant species found within their village and the adjoining Baruni (Nongmaiching) Hills. Every elderly people of Andro have common knowledge and easy cure for many common aliments and most of the elderly people uses and prepare different types of medicines from different plant parts. A total of 29 medicinal plant species belonging to 27 genera and distributed over 19 families were found to be used by the schedule caste community of Andro in the treatment of rectum disease-piles. Some of the species used are Acacia farnesiana (Linn.) Willd., Azadirachta indica A.Juss., .Chamaesvce hirta (L.) Millsp, Elsholtzia blanda (Benth.) Benth., Hedychium coronarium Koenig ex Retz., Lantana camara Linn., Leucaena leucocephala (Lamk.) de Wit, Nicotiana plumbaginifolia Viv., Xylosma longifolium Clos etc.
\end{abstract}

Keywords: Scheduled Caste Community, Andro, Manipur, Piles, Traditional Knowledge

\section{Introduction}

The traditional storage of ethnobotanical knowledge in memory and practice has a long history. At least 6500 species of plants are used locally in Asia in traditional and folk medicines. Several Asian countries have begun to encourage traditional medicines as an integral component of health care system.

The use of plants and animals as source of medicine and food is as old as humanity. The therapeutic hints from remote mists of time hold key of the treasures of medical knowledge. From the large array of hints and claims, the investigator of today has to promulgate the best and beneficial, and recant one not useful. According to studies on ethnomedicine and folk medicine about 2000 species of plants are newly identified as drug yielding plants and are well known for their use in about 4000 drug industries of various Indian system of medicine. It is estimated that about 7500 plants are used in local health traditions in mostly rural and tribal villages of India. Out of these, the real traditional medicine value of over 5000 plants is either little known or hitherto unknown to the mainstream population [1].

According to a report over 16000 species of higher plants are reported to occur in India and out of these 9000 are economically useful whereas 7500 of these species are reported to be used for health care by various ethnic communities in India [2]. India officially recognizes over 2500 plants as having medicinal value and it has been estimated that over 6000 plants are used in traditional, folk and herbal medicines. The number of medicinal plants in India both indigenous and introduced has been variously put at between 3000 to 3500 species of higher plants. 
North-Eastern region of Indian sub-continent harbours $50 \%$ of the plant wealth of India [3]. The state of Manipur is included under the "Indo-Burma Hot spot". Manipur has also a rich diversity of flora and a large number of economic and medicinal plants. According to reports by the Botanical Survey of India [4], the state harbours over 3500 species of higher plants and is an important source for germplasm.

A pile is an illness that gives excruciating pain to the patients because of a swollen rectum. Haemorrhoids are the most common piles and painful to patients. Haemorrhoids (Piles) are swellings that develop from the lining of the anus and lower rectum. Manipur has its own scope for ethnobotanical studies since it is inhabited by numerous scheduled tribe and scheduled caste communities. Manipur is very rich in the resource of folk medicine and it had been functioning by a pluralistic society It is through the folk medicine that many traditional healers "Maiba" (male medical practitioners) and "Maibis" (female medical practitioners in Manipuri) can cure effectively certain diseases and ailments like snake bite, dog bite, bone setting etc. A good number of papers have been published in recent years on the Ethnobotany of Manipur with main emphasis on medicinal plants $[5,6,7,8,9,10,11]$. However there is practically no paper concerning the ethnomedicinal uses of plants in the treatment of piles in India. Thus in this paper an attempt is made to enumerate the use of plants in the treatment of piles by a small realistic community of Andro in Manipur (India).

\section{Materials and Methods}

\subsection{Study Area}

The present study site Andro village is located at the foothills of the Baruni (Nongmaiching) hills at a distance of about $24 \mathrm{~km}$ from Imphal the capital city of Manipur along the Imphal-Ngariyan hill road. The study site is included under the Imphal East District of Manipur. Andro village is one of the oldest villages in Manipur. The exact location of Andro village is at the intersection of $94^{\circ} .2 \mathrm{E}$ longitude and $24^{0} .44^{\prime} \mathrm{N}$ latitude. The elevation of Andro is about $783 \mathrm{~m}$ above the mean sea level. It has an area of about $4.0 \mathrm{~km}^{-2}$. Andro is surrounded by Sanapat in the east, Uchon on the south, Maringthel in the west and Baruni (Nongmaiching) Hills on the north. The inhabitants of this village are listed as a scheduled caste group of Manipur under the Scheduled Castes and Scheduled Tribes orders (Amendments) Act 1956 (Act no. 6 of 1956). The groups which are generally known as 'Lois' have been included in the list of scheduled castes and tribes of Manipur.

The word Andro is derived from the word "Handro" meaning return back after a long separation. The people of Andro belong to the 'Chakpas'. They still maintain their caste solidarities with a primitive state of economic life. Hey depend mostly on surrounding plant communities with traditional agriculture as a primary means of livelihood. Andro village is divided into thirteen Localities (Leikais in
Manipuri). The people of Andro have its own origin, tradition, culture and history and still maintaining their realistic ideology.

One of the most interesting places in Andro is a big building known as "Meihoupham" or "Starting place of fire" which is situated in the heart of the village. According to the villagers it is supposed to be the oldest fire place in the world. Since time immemorial the fire in this fireplace is burning continuously till today and will do so in future. It is believed that this fire is the real, endless, continuous and living fire in this planet which is supposed to be present since the very beginning of the creation of the earth in this universe. The task of maintaining the fire is borne by each and every household of the thirteen sub-villages as their unavoidable duty in a routine manner.

There are extreme rules and regulations as "do's" and "don'ts" regarding food habit, untouchability, breach of taboos etc. Each and every people of Andro have common knowledge and easy cure for many simple and common diseases like cold, cough, dysentery, diarrhoea, fever, burns, headaches etc.

Apart from Natural folk medicine and magico-religious folk medicines, a third type of treatment is also practiced by most people of this community. Here the local medical practitioners manipulated or messaged the different body parts, organs, veins, arteries, bones etc. which can improve the bodies fight against diseases. This type of treatment system is locally known as "Khutli-Shuba". In fact the local practitioners knew the physiology, anatomy, muscle structures, palpitation rhythm of human body and their functions very well.

\subsection{Ethnomedicinal Study of Plant Species}

The paper is based on the data collected on ethnomedicinal practices among the people of Andro Village during January 2012 to December, 2012. For the present study all the 13 localities under Andro village have been exhaustively investigated ethnobotanically using standard methods for the collection of ethnobotanical informations $[12,13,14,15,16,17]$.

Three ethnomedicine specialists or local medical practitioners $($ Maiba $=$ Male and Maibi $=$ Female in Manipuri) were contacted from different localities of Andro Village. Elderly persons, heads of the settlements and persons having thorough knowledge of medicinal plants and their utilization in day-to-day life were also consulted. The information gathered from one group or locality was compared with those collected from other groups. After detailed interview data were collected, based on the nature and use of medicinal plants in controlling and curing of piles.

\section{Results \& Discussion}

\subsection{Results}

In the present enumeration each botanical name is 
followed by its family, local name (Manipuri), and common English names if any, part or parts used in the preparation and method of preparation and mode of use. Efforts have also been made to find out the correct botanical names in accordance with the latest International Code of Botanical Nomenclature (ICBN). The correct authors' names have also been given as per Authors of plant names of Royal Botanic Garden, Kew [18]. Colour photographs were also taken for most of the species and herbariums were also prepared for the collected specimens and the same have been deposited in the Botany Department of Thoubal College, Thoubal (Manipur), India for future use.

1. Acacia farnesiana (Linn.) Willd. Family: Mimosaceae.

Local name: Chingonglei hangampal. Common name: Cassie flower.

Distribution: Common, grows wild.

Description: It is a tall shrub. Leaves are sessile and small pinnate type. Leaflets are membranous and 10 to 12 pairs in numbers. Small stipular spines are present on the stem and branches. Flowers are yellow in colour in globose head. A bunch of such globose head arises from a nodal point and off the same mature type.

Parts used: Leaves.

Ethnomedicinal uses: Decoction of the leaves is used in piles.

2. Allium sativum Linn.

Local name: Chanam.

Family: Liliaceae.

Distribution: Commonly cultivated edible leaves and bulbs.

Description: It is a perennial herb having a short axis that are circular and flat on the top, giving off slender fibrous rootlets below and from the crown several very thin, shining, papery scales which are large and much dilated below bearing in their axils large, oblong-ovoid, pointed, solid, sessile bulbs that are unequal, compressed together and the outer ones curved so as to form collectively an ovate and lobed white bulb. Flowers are terminal in position, singly through the centre of the bulb. Leaves arise from the rootstocks.

Parts used: Bulbs.

Ethnomedicinal uses: The bulb of the plant cooked in milk and eaten in piles.

3. Allium tuberosum Rottb. ex Spreng.

Family: Liliaceae. Local name: Maroi nakuppi. Distribution: Commonly cultivated throughout the village.

Description: It is a soft leathery herb having tunicate bulbs. Leaves are many out of which the basal ones are very narrowly linear, flattish, keeled and shorter than the terete slender scape. Pedicels are longer than the small whitish companulate perianth.

Parts used: Leaves.

Ethnomedicinal uses: Boiled extract of the leaves is prescribed orally against piles.
4. Alpinia galanga (Linn.) Swartz.
Family: Zingiberaceae.

Local name: Kanghu. Common name: Greater galangal.

Distribution: Rare, grows wild in the wastelands. Sometimes cultivated.

Description: Plant is herbaceous having tuberous aromatic root stocks. Leaves are large, oblong-lanceolate, acute, green above and paler below having long and glabrous sheaths. Flowers are greenish white in dense flowered panicles where the branches are short and rachis is pubescent. The size of the fruit is like the size of a small cherry and orange-red in colour.

Parts used: Rhizomes.

Ethnomedicinal uses: Boiled extract of the rhizome is prescribed orally against piles.

5. Amaranthus gangeticus Linn. Family: Amaranthaceae.

Local name: Chengkruk angangba. Common name: Red amaranth.

Distribution: Commonly cultivated for the edible shoots and leaves.

Description: It is a herbaceous plant with the stem bearing soft, small spines. Leaves are lanceolate, obtuse and glabrous. Flowers are with bracteoles. In the axils flowers are present in a cluster manner.

Parts used: Stem and leaves.

Ethnomedicinal uses: Boiled extract of the aerial plant parts in mixed with an equal volume of the boiled extract of whole plant of Centella asiatica (Linn.) Urban (Local name-Peruk) and the decoction mixture is taken one yaum (approximately equal to 5 or 6 teaspoon) per day for 4 to 6 days in constipation and piles.

6. Azadirachta indica A.Juss. Family: Meliaceae.

Local name: Nim. Common name: Margosa tree.

Distribution: Rare and occasionally planted in the village.

Description: It is a tall tree with rough, grayish or brownish bark. Leaves are alternate and pinnately compound with serrated margins. Flowers numerous in axillary panicles and are white in colour.

Parts used: Tender branches.

Ethnomedicinal uses: The decoction of the tender branches is very good for piles. The patient is made to be seated in the concentrated hot decoction for a few minute daily for about one week.

7. Carica papaya Linn.

Local name: Awathabi.

Family: Caricaceae.

Distribution: Very commonly cultivated.

Description: It is a fast growing soft tree, rarely branched. Leaves are large with long petioles, variously incised or deeply lobed forming a bunch at the top of the plant. Stem is cylindrical and hollow with many leaf scars

Parts used: Milky latex.

Ethnomedicinal uses: Latex is also used to improve piles.

8. Celtis australis Linn. Family: Ulmaceae.

Local name: Heikreng. Common name: European nettle tree.

Distribution: Very rare.

Description: It is a big tree. Leaves deciduous, very obliquely ovate, coarsely serrate and entire towards the base. 
The bark is irregular and ugly to look at due to infection by microorganisms. Ovary is ovoid in structure.

Parts used: Leaves.

Ethnomedicinal uses: The people of Andro prescribed the decoction of the leaves against piles externally.

9. Clerodendrum colebrookianum Walp. Family: Lamiaceae.

Local name: Kuthap. Common name: Turk's turban.

Distribution: Very common in the foothills and wastelands.

Description: Plant is a shrub. Leaves are glabrous, cordate, acute and ovate. Petioles are long. Flowers white in colour. Corolla with slender tubes. Fruit bluish green in colour and globose in shape.

Parts used: Leaves.

Ethnomedicinal uses: Patients suffering from piles and worm infections are made to sit in the hot decoction of the leaves for 10 to 15 minutes. It will reduce irritation.

10. Cycas pectinata Griff. Family: Cycadaceae.

Local name: Yendang. Common name: Palm fern.

Distribution: Grow wild mostly in the hill slopes; sometimes planted in the homestead compounds as an ornamental and also for the edible leaves.

Description: It is an arboreal plant up to $3.5 \mathrm{~m}$ tall looking like a palm tree or a small tree fern. The stem bears a crown of recurved leaves with flat, narrow and linear leaflets. A few spines are present at the base of the petiole. The male cones are shortly peduncled, cylindrical-ovoid and up to $40 \mathrm{~cm}$ long. The megasporophylls have pectinate leaf blades and bear 4-6 glabrous ovules on their stalks.

Parts used: Female cones.

Ethnomedicinal uses: Boiled extract of the female cone with honey is prescribed against piles.

11. Cynodon dactylon (Linn.) Pers. Family: Poaceae.

Local name: Tingthou. Common name: Dog grass.

Distribution: Very common throughout the valley.

Description: It is a creeping herb with slender and prostrate stem extensively creeping by scaly rhizomes. Leaves are lanceolate, linear and more or less glaucous. The floral glumes are obliquely oblong.

Parts used: Whole plant.

Ethnomedicinal uses: The fresh juice extract of the whole plant along with honey is prescribed orally against uterine bleedings and piles.

12. Chamaesvce hirta (L.) Millsp Syn. Euphorbia hirta L. E. pilulifera L Family: Euphorbiaceae.

Local name: Pakhang leiton. Common name: Snake weed.

Distribution: Very common both in the valley in moist situations.

Description: It is a soft herb. Leaves are obovate, obtuse or rounded with oblique or rounded base. Lobes of the involucres are narrowly lanceolate, acuminate and longer than the shortly stipitate glands. Seeds are smooth or with shallow transverse pits.

Parts used: Whole plant.

Ethnomedicinal uses: Decoction of the plant is useful in bleeding piles.

13. Elsholtzia blanda (Benth.) Benth.

Syn. Perilla elata D.Don Family: Lamiaceae.

Local name: Kanghu man. Common name:

Bengal sage.

Distribution: Common and cultivated for the leaves which are used as condiment.

Description: It is a small shrub having tomentose shoot possessing specific smell. The leaves are oblong, lanceolate and long petioled. The flowers are in dense terminal spikes, white in colour. A cluster of dense growth of this plant could be seen in a particular area during the rainy season.

Parts used: Inflorescence.

Ethnomedicinal uses: Extract of the inflorescence is used in piles.

14. Hedychium coronarium Koenig ex Retz. Family: Zingiberaceae.

Local name: Takhellei angouba. Common name: Ginger lily.

Distribution: Grows wild and planted in the homestead compounds for the beautiful, scented flowers \& edible rhizomes.

Description: It is a perennial herb having horizontal tuberous rootstocks. Leaves are oblong or oblong-lanceolate. Flowers are white with yellow tinge and staminodes are oblong or oblong-lanceolate. The lips are broad, shallowly bifid and distinctly clawed.

Parts used: Rhizomes.

Ethnomedicinal uses: Decoction of the rhizomes is used against piles.

15. Jasminum multiflorum (Burm.f.) Andrews Family: Oleaceae.

Local name: Kundo. Common name: Dawny jasmine.

Distribution: Usually cultivated for religious uses.

Description: It is a scandent shrub growing in clusters with soft stem. Leaves are simple, acuminate and entire, opposite with pubescent petioles. Flowers are white, sweetly scented and sub-sessile. Fruits black when mature.

Parts used: Flowers.

Ethnomedicinal uses: Boiled extract of the flowers is prescribed orally in piles.

16. Lantana camara Linn. Family: Verbenaceae.

Local name: Thirei /Nongbanlei. Common name: Lantana.

Distribution: Very common, sometimes planted as wall fencing. Description: Plant is a shrub. Stem is herbaceous and quadrangular, hairy with recurved soft spines; lower portion of the stem is woody. Leaves are simple, opposite, petiolate, surface rough and unicostate. Inflorescence axillary peduncled head or spike. Flowers bracteate, sessile and complete and variously coloured.

Parts used: Leaves/shoot tips.

Ethnomedicinal uses: The fresh extract of the leaves or shoot tip after crushing is mixed with honey is a good remedy for piles commonly use by the people of this community. It is given one yaum (5 to 6 teaspoonfuls) two to 
three times a day for 4 to 7 days. Its use in piles is also done in another way as follows - the patient is made to sit in the hot decoction of the leaves in a wide mouthed vessel.

17. Leucaena leucocephala (Lamk.) de Wit Family: Mimosaceae.

Local name: Chingonglei angouba.

Common name: White popinae.

Distribution: Common in the villages. Sometimes grown in homestead compounds for the edible leaves, flowers and fruits.

Description: Plant is tall and erect shrub. Leaves are small while the leaflets are pinnately compound and membranous. Spines are present on the stem and branches. Flowers are white forming a dense globose head.

Parts used: Leaves.

Ethnomedicinal uses: Decoction of leaves is used in piles. 18. Mimosa pudica Linn. Family: Mimosaceae.

Local name: Kangphal ekaithabi. Common name: Sensitive plant.

Distribution: Very common.

Description: It is a prostrate, diffused herb. Many small prickles are present on the aerial plant parts. Stem is herbaceous, solid and hairy. Leaf base is pulvinous. Leaves fold automatically when touched. Flowers pink in colour. Fruit is a lomentum.

Parts used: Whole plant.

Ethnomedicinal uses: The whole plant is mixed with the leaves of Eucalyptus globulus Labill. (Local name-Nasik) and boiled for a long time and the decoction is used in bleeding piles.

19. Nicotiana plumbaginifolia Viv.

Family: Solanaceae. Local name: Meitei hidak mana.

Distribution: Common in wastelands but sometimes cultivated.

Description: It is a pubescent annual herbaceous plant. Stem is soft and slender. Leaves are sticky; margin is entire, lanceolate to obovate-spathulate. Flowers are white in colour in terminal racemes cymes.

Parts used: Leaves.

Ethnomedicinal uses: A mixture of the dried leaves along with those of Azadirachta indica A. Juss. (Local name-Nim) are roasted together in a closed container. The steam or smoke coming out through a small hole is allowed to come in contact with the anus of persons suffering from piles. This practice is widely used by the people of this community.

20. Oroxylum indicum (Linn.) Vent Family: Bignoniaceae.

Local name: Samba. Common name: Trumpet flower.

Distribution: Rare, grows wild in forest. Sometimes cultivated for its medicinal uses.

Description: Plant is a big, tall tree. Stem is covered with light brown bark. Leaves are very large and opposite. Fruits are very long like a sword. Seeds are winged and numerous.

Parts used: Bark.

Ethnomedicinal uses: Decoction of the bark is also very important in the treatment of piles.

21. Terminalia chebula Retz. Family: Combretaceae.
Local name: Manahi.

Chebulic myrobalan.

Distribution: Grows wild in the forests of Manipur.

Description: It is a large deciduous tree. The leaves are ovate or elliptic. The inflorescence is a panicled spike. Flowers are whitish yellow and scented. Fruit is ovoid or obovoid and five ribbed drupe.

Parts used: Fruits.

Ethnomedicinal uses: The fruit is crushed with the rhizomes of Zingiber officinale Rosc. (local name-Shing); bark of Albizia myriophylla Benth. (local name-Yangli) and leaves of Mentha arvensis Linn.(local name-Nungshi hidak) using a little water. Sugar candy or honey is added to the extract and the same is prescribed for 4 to 6 days, one yaum (equivalent to 5 or 6 teaspoonful) in piles,

22. Vitex trifolia Linn.

Local name: Urik shibi.

Family: Lamiaceae.

Common name:

Chinese chaste tree.

Distribution: Common and grows wild sometimes planted as hedge plant around homestead compounds.

Description: Plant is a shrub having smooth pale grayish bark. Leaves are variable; leaflets are elliptical or oblong-ovate, usually obtuse where the terminal leaflets are sessile. Flowers are blue in colour and are in pedunculate tomentose cymes and are in opposite along the tomentose rachis of a terminal panicle. Bracts are minute.

Parts used: Leaves.

Ethnomedicinal uses: The Boiled extract of the leaves mixed with honey is prescribed orally by the people of this community in the treatment of piles.

\section{Xylosma longifolium Clos}

Family: Flacourtiaceae. Local name:

Nongleishang. Distribution: Grows wild in the forest and sometimes planted in the homestead compounds for its medicinal properties.

Description: It is a tall tree. Leaves are oblong or elliptic, lanceolate, serrate with recurved margin. Flowers yellow in panicles of axillary racemes.

Parts used: Leaves.

Ethnomedicinal uses: The decoction of the leaves alone or mixed with the leaves of Azadirachta indica A. Juss. (Local name-Nim) are used in the treatment of piles.

24. Zingiber purpureum Rosc.

Family: Zingiberaceae. Local name: Tekhao yaikhu.

Distribution: Wild and sometimes cultivated.

Description: It an herb with elongated leafy stems and horizontal tuberous rootstocks. Leaves are sub-sessile, oblong-lanceolate with pubescent sheaths. Flowers are in dense fusiforrm or oblong ellipsoid spikes. The peduncles are with numerous oblong sheaths. Bracts are broadly ovate and pubescent with narrow membranous margins.

Parts used: Rhizomes.

Ethnomedicinal uses: The soup obtained by boiling the rhizome along with crab is prescribed in leucorrhoea, bleeding piles. 


\subsection{Discussion}

The present study reveals that 29 plant species were found to be used by the scheduled caste community of Andro in the treatment of piles. These 29 plant species belongs to 27 genera which are distributed over 19 families (15 dicotyledons, 3 monocotyledons and 1 gymnosperm).

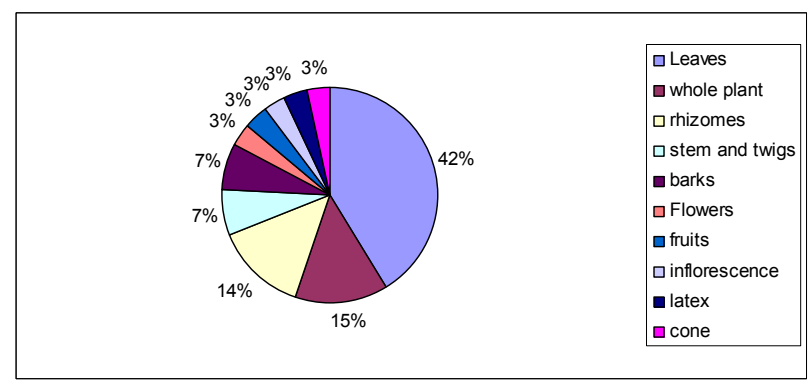

Fig 1. Distribution of different plants parts used.

The families Zingiberaceae, Lamiaceae and Mimosaceae with 4 species each have contributed maximum number of species in the treatment of piles which is followed by Liliaceae with 2 species. The remaining 15 families have only 1 species each used in piles treatment (Figure 1).

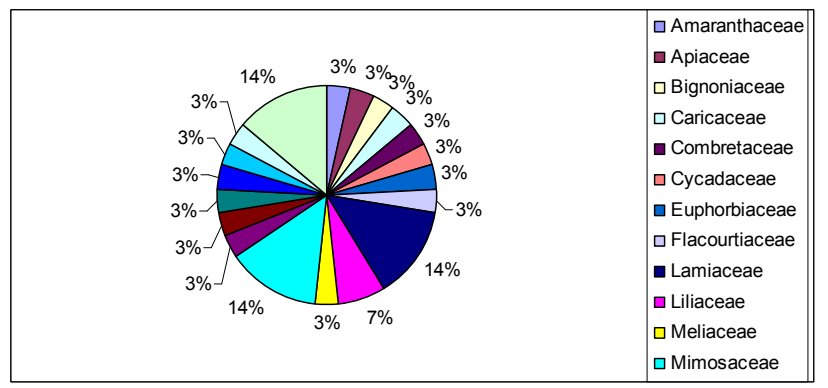

Fig 2. Distribution of different species.

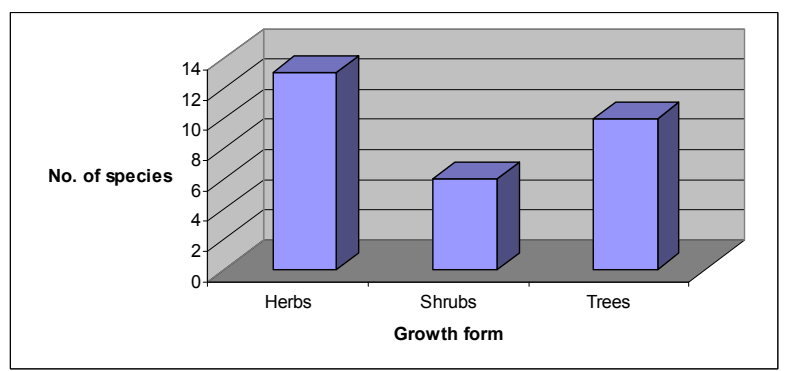

Fig 3. Growth form distribution of the species

Out of the 29 species recorded, 13 species are herbaceous plants, 6 shrubs and 10 trees (figure 2). For the treatment of piles, the use of above ground plant parts was higher $(82.75 \%)$ than the underground parts (17.24\%). Leaves were used in the majority of the cases (12 species), followed by whole plant and rhizomes (4 species each), barks (2 species) and stem and twigs (2 species). Flowers, fruits, inflorescence, bulbs, latex and cone of gymnosperms are represented by 1 species each (Figure 3). Further research is necessary to ascertain the exact number of plants being used by this scheduled caste community along with the exact methods of treatment.

\section{Conclusion}

The present study documented the traditional uses of medicinal plants used in the treatment of piles by the people of Andro Village, a small scheduled caste village in Manipur (India). This study can serve as baseline information on the medicinal plants wealth of this small realistic community. Further investigation will throw more light about the vast wealth of ethnobotanical information possessed by this community.

\section{Acknowledgements}

The authors are thankful to the Local Medical Practitioners of Andro Village in particular and the people of Andro in general for their kind cooperation during the many field trips. The second author is also thankful to the University Grants Commission (North Eastern Region), Guwahati (India) for financial assistance in the form of a Minor Research Project.

\section{References}

[1] Pushpangadan P., Nyman Ulf and George V. Proceeding of the First National Conference on Ethnopharmacology. Visual Security Printing Enterprises Pvt. Ltd. New Delhi (India) 1995.

[2] Arora, R.K. Ethnobotany and its role in the conservation and use of plant genetic resources in India. Ethnobotany 9: 6-15, 1987.

[3] Rao, R.R. Ethnobotany of Meghalaya-Medicinal plants used by Khasi and Garo tribes in Meghalaya. Econ Bot 34:4-9, 1981.

[4] Singh, N.P., Chauhan, A.S. and Mondal, M.S. Flora of Manipur Vol. I. Botanical Survey of India, Calcutta 2000.

[5] Sharma, H.M. and Devi, A.R. Ethnomedicinal uses of plants in the treatment of urinary tract diseases by the Meiteis of Manipur. In Ethnomedicinal Plants. Edited by Trivedi, P.C. and Sharma N.K. Pointer Publishers, Jaipur (India) 151-159, 2004.

[6] Sharma, H.M., Sharma, B.M. and Devi. A.R. Contributions to the edible fruits of Manipur. Journal of Economic and Taxonomic Botany 23(2): 615-623, 1999.

[7] Sharma, H.M., Devi, A.R., and Sharma, B.M. Ethnomedicinal uses of monocotyledonous plants by the Meiteis of Manipur. In Ethnobotany and Medicinal plants of India and Nepal. Edited by Singh, V. and Jain, A.P. Scientific Publishers, Jodhpur (India) 473- 480, 2003.

[8] Sharma, B.M., Sharma, H.M. and Devi, A.R. Ethnomedicinal uses of plants by the Manipuris (Meiteis) of Manipur. In Recent Progress in Medicinal Plants. Vol. 7. Ethnomedicine and Pharmacognosy II . Edited by Singh, V.K., Govil, J.N., Hashmi, S. and Singh, G. Studium Press LLC, (Houston), USA 523-541, 2003. 
[9] Singh, T.T., Devi, A.R., Sharma, H.R. and Sharma, H.M. Plants used in the treatment of Boils, Blains and Ulcers by the Scheduled Caste Community of Andro in Imphal East District, Manipur (India). In Bioresources and Traditional Knowledge of Northeast India. Edited by Singh, K.K., Das, K.C. and Lalruatsanga, H. Mizo Post Graduate Science Society, Aizwal (India) 279-289, 2013.

[10] Singh, H.B., Singh, R.S. and Sandhu, J.S. Herbal Medicine of Manipur. A Colour Encyclopedia. Daya Publishing House, New Delhi (India) 2003.

[11] Sinha, S.C. Medicinal Plants of Manipur. Sinha and MASS Publication, Imphal (India) 1996.

[12] Jain, S.K. and Goel, A.K. Workshop Exercise I: Proforma for field work. In A Manual of Ethnobotany. Edited by Jain, S.K. Scientific Publishers, Jodhpur (India) 142-153, 1987.

[13] Jain, S.K. and Mudgal, V. A Hand Book of Ethnobotany. Bishen Singh and Mahendra Pal Singh, Dehradun (India) 1999.
[14] Jain, S.K. and Rao. R. R. A Hand Book of Field and Herbarium Methods. Today \& Tomorrow's Publishers, New Delhi (India) 1977.

[15] Kapoor, S.L. and Mitra, R. Form for botanical and ethno-pharmacognostic investigation of a plant used in traditional medicine. In A Manual of Ethnobotany. Edited by Jain, S.K. Scientific Publishers, Jodhpur (India) 155- 157, 1987.

[16] Martin, G.J. Ethnobotany - A Methods Manual. Chapman and Hall, London 1994.

[17] Anonymous. All India Coordinated Research Project on Ethnobiology. Man and Biosphere Programme (MAB). Ministry of Environment and Forests, Government of India 1984.

[18] Brummit, R.K. and Powell, C.E. Authors of Plant Names. Royal Botanic Gardens, Kew (England) 1992. 